\title{
Palladium Nanoparticles Fabricated by Green Chemistry: Promising Chemotherapeutic, Antioxidant and Antimicrobial Agents
}

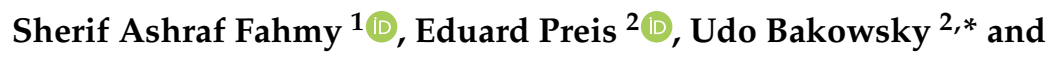 \\ Hassan Mohamed El-Said Azzazy ${ }^{1, *}$ \\ 1 Department of Chemistry, School of Sciences \& Engineering, The American University in Cairo, \\ AUC Avenue, P.O. Box 74, New Cairo 11835, Egypt; sheriffahmy@aucegypt.edu \\ 2 Department of Pharmaceutics and Biopharmaceutics, University of Marburg, Robert-Koch-Str. 4, \\ 35037 Marburg, Germany; eduard.preis@pharmazie.uni-marburg.de \\ * Correspondence: ubakowsky@aol.com (U.B.); hazzazy@aucegypt.edu (H.M.E.-S.A.); \\ Tel.: +49-(0)6421-282-5884 (U.B.); +20-2-2615-2559 (H.M.E.-S.A.)
}

Received: 19 July 2020; Accepted: 17 August 2020; Published: 19 August 2020

\begin{abstract}
Palladium nanoparticles (Pd NPs) showed great potential in biomedical applications because of their unique physicochemical properties. Various conventional physical and chemical methods have been used for the synthesis of Pd NPs. However, these methods include the use of hazardous reagents and reaction conditions, which may be toxic to health and to the environment. Thus, eco-friendly, rapid, and economic approaches for the synthesis of Pd NPs have been developed. Bacteria, fungi, yeast, seaweeds, plants, and plant extracts were used to prepare Pd NPs. This review highlights the most recent studies for the biosynthesis of Pd NPs, factors controlling their synthesis, and their potential biomedical applications.
\end{abstract}

Keywords: green synthesis; plant extracts; palladium nanoparticles; anticancer activity; antibacterial activity; antioxidants

\section{Introduction}

Palladium nanoparticles (Pd NPs) have significant chemical and thermal stabilities, electronic properties, and optical properties [1,2]. They could also be biofunctionalized to enable their medical applications [3,4]. Moreover, Pd NPs were used as photothermal agents, drug carriers, and prodrug activators. They possess antimicrobial, antioxidant, and cytotoxic activities [2,5,6]. Several studies reported on the synthesis of Pd NPs using hazardous, expensive, and multistep conventional techniques such as sol-gel, chemical reduction, and electrochemical and chemical precipitation [1,2].

However, in the past few years, there has been a growing interest in utilizing green chemistry in the production of Pd NPs using eco-friendly and biocompatible bio-derived products, including microorganisms (such as bacteria, viruses, fungi, and yeast) and seaweeds [7-21]. In addition to these bio-derived products, utilizing plant extracts in the biosynthesis of Pd NPs (phytosynthesis) was suggested to be advantageous over other bio-derived materials. Unlike microorganisms and seaweeds, using plant extracts for the biosynthesis of Pd NPs is simple, rapid, and cost-effective. Furthermore, the phytosynthesis process can easily be optimized for large-scale production of more stable Pd NPs. On the other hand, plant extracts harbor various bioactive metabolites that could act as natural reducing and capping agents during the phytosynthesis of Pd NPs [22-25]. To achieve phytosynthesis, sonication, microwave, magnetic, and hydrothermal methods are employed along with non-hazardous solvents and lower temperatures [7]. This review covers the state-of-the-art in green synthesis of Pd NPs as well as their biomedical applications. 


\section{Green Synthesis of Pd NPs}

Microorganisms (MOs), algae, and plant extracts were used for the bioreduction of metals [26-28]. The biosynthesis of Pd NPs is a safe, clean, and eco-friendly approach to produce NPs of versatile sizes, shapes, physical, chemical, and biological properties [29].

The use of MOs (specially fungi) in the green synthesis is promising because they are abundant and can bio-reduce Pd ions via enzymatic activity, converting them into Pd atoms while maintaining proper control over the sizes of the NPs through bio-patterning [30,31]. However, the use of MOs in the green synthesis involves a sophisticated and time-consuming multistep process. The localized heating (employing microwave heat, for instance) needed for the NPs to be created could deform the MOs enzymes required for the bioreduction to take place [29,32]. Additionally, many aspects should be considered in the process of producing Pd NPs using MOs, such as the careful selection of the most appropriate $\mathrm{MO}$ because each one interacts differently with metal ions according to the intrinsic enzymatic activity and biochemical processes. Additionally, culturing methods and conditions (such as light, temperature, $\mathrm{pH}$, inoculation, and nutrients) are very crucial and should be optimized. A sterile environment should be maintained to prevent contamination with other MOs. Finally, reaction conditions should be controlled upon mixing the $\mathrm{MO}$ with the metal ions to obtain a large scale and stable Pd NPs with well-defined size and morphology [7-21]. Hence, the use of MO suffers many drawbacks, which makes its employment in the green synthesis of Pd NPs challenging.

Algae have recently been reported in the biosynthesis of Pd NPs [33]. They are rich in broad-spectrum bioactive compounds and natural reducing agents, making them very promising in the biogenic synthesis of Pd NPs. Additionally, they are easily harvested, scalable, and their surfaces possess negative charges facilitating the nucleation and growth of the nanoparticles. Hence, algae can be used for low-cost large-scale production of Pd NPs. Various types of algae, including red, brown, and green algae, were used for biosynthesis and tailoring of Pd NPs [33,34].

Contrary to MOs, the use of plant extracts in the biosynthesis of Pd NPs has attracted much attention in the past few years because of their advantages over other biological entities. The green synthesis of Pd NPs using plant extracts is a single-step process that does not require the elaborate steps of isolation, culture optimization, and maintenance [7-23]. Moreover, the use of plant extracts is cost-effective, safe, rapid, and is easier to scale up. Additionally, the Pd NPs produced via phytosynthesis are more stable and are created at faster rates compared to MO. Plants are rich in various bioactive secondary metabolites and organic reducing agents such as phenols, flavonoids, alkaloids, saponins, vitamins, aldehydes, and steroids [8,9,35-38]. These compounds play the primary role in the phytosynthesis of the Pd NPs via bioreduction of the metal ions and stabilizing the resulted $\mathrm{Pd}$ NPs $[8,9]$. Hence, many studies reported the use of plants and plant extracts for the rapid biosynthesis of various stable Pd NPs using environmentally friendly approaches [39-41].

Some plants also possess therapeutic actions such as antimicrobial, anticancer, or antioxidant activities. Hence, they impart a synergistic therapeutic effect upon their combination with $\mathrm{Pd}$ NPs [24,25].

\section{Mechanism of Biogenic Synthesis of Pd NPs}

The biosynthesis of the Pd NPs generally involves mixing the metal salt solutions with the plant extract at room temperature, and the nanoparticles are created rapidly and indicated by the change in color of the reaction medium [42]. However, many parameters should be optimized to control the shape, size, and crystallinity of Pd NPs, including the origin of the biological extract and its concentration, metal salt concentration, the temperature of the reaction media, $\mathrm{pH}$ of the reaction media, rate at which extract is added, and the contact time [43-47]. While the exact mechanism of the biosynthesis of Pd NPs are not well known and more studies are required, a fundamental bottom-up mechanism involving four major steps is suggested (Figure 1) [48,49]. The initial activation step in the biosynthesis of Pd NPs is the bioreduction and nucleation of the metal ions at which the metal ions are reduced into their zero-oxidation states [50]. The second step involves the subsequent growth and 
agglomeration of the small Pd NPs into larger and more thermodynamically stable Pd NPs. Then, a termination step occurs where a variety of Pd NPs shapes are created, depending on the optimized conditions, such as spheres, rods, triangles, wires, pentagons, or hexagons [50,51]. During this phase, stabilization of the Pd NPs is undertaken via the plant extract, which contains various functional groups that could act as capping agents such as alcohols, aldehydes, amines, carboxylic acid, and ketones [50]. Finally, the biosynthesized Pd NPs are purified and washed via centrifugation [51]. It is worth mentioning that few recent studies reported on the use of supramolecules (macromolecules) such as calix[n]arenes and cyclodextrins as potential stabilizing agents for the biosynthesized $\mathrm{Pd}$ NPs [52-56]. They have been chosen as promising capping agents due to their biocompatible and eco-friendly nature [57]. Macromolecules could act as capping agents via surface attachment on the targeted Pd NPs through a combination of hydrophobic, charge transfer, hydrogen bonding, covalent bonding, or ion-dipole interactions (Figure 1) [58-60].

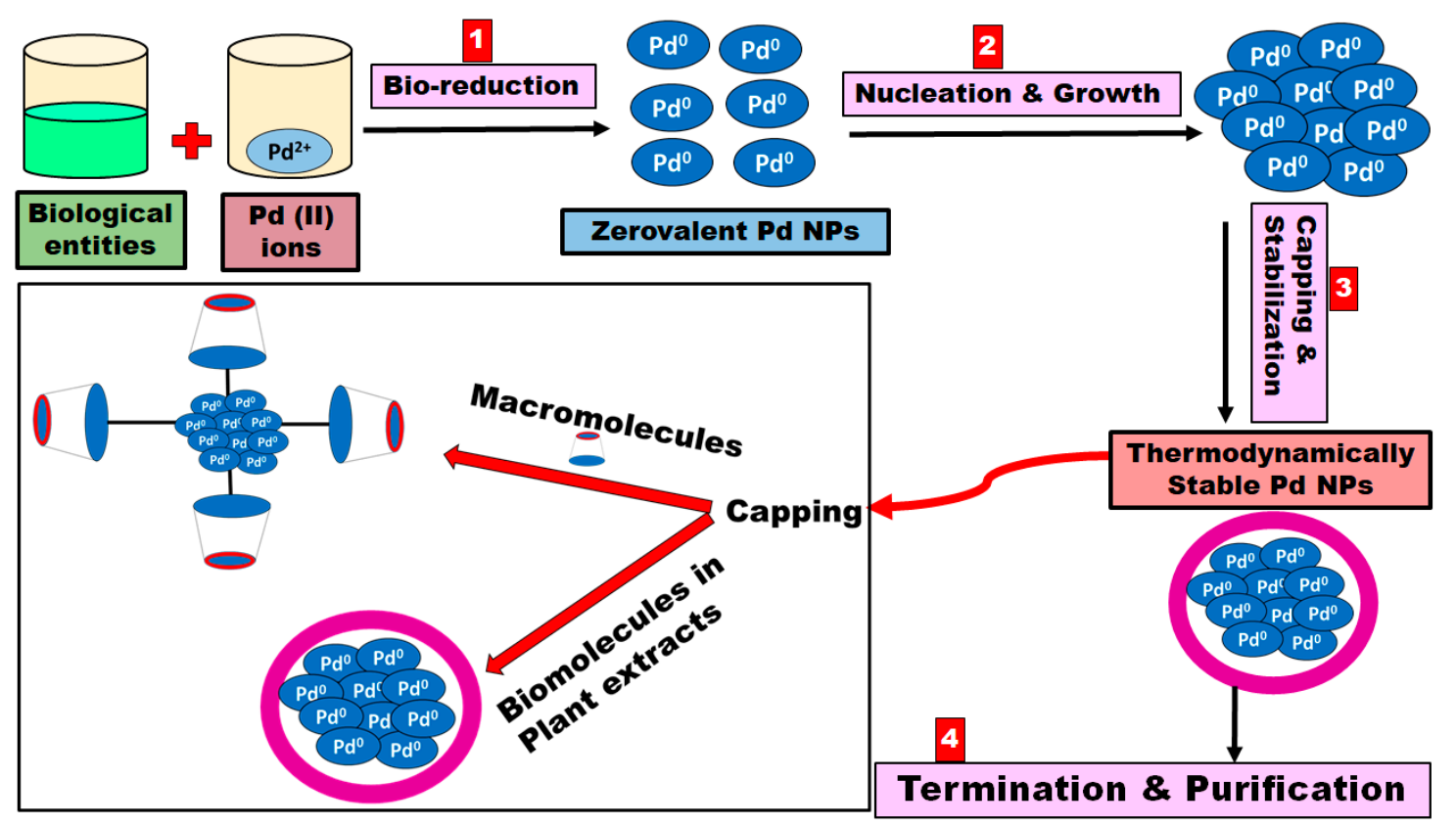

Figure 1. Schematic diagram representing the four-step mechanism for the biosynthesis of Pd NPs.

\section{Phytosynthesis of Pd NPs}

Pd NPs are biosynthesized using various plant species, and the sizes, shapes, monodispersity, yield, and crystallinity of the fabricated nanoparticles are controlled by optimizing the synthesis conditions (Figure 2 and Table 1) [61,62]. The prepared Pd NPs were characterized using UV/Vis spectrophotometry, dynamic light scattering (DLS), scanning electron microscopy (SEM), transmission electron microscopy (TEM), Fourier transform infrared spectroscopy (FTIR), and powder X-ray diffraction (XRD). Spectroscopic and diffractographic techniques play a crucial role in the identification and characterization of Pd NPs [61,62]. 


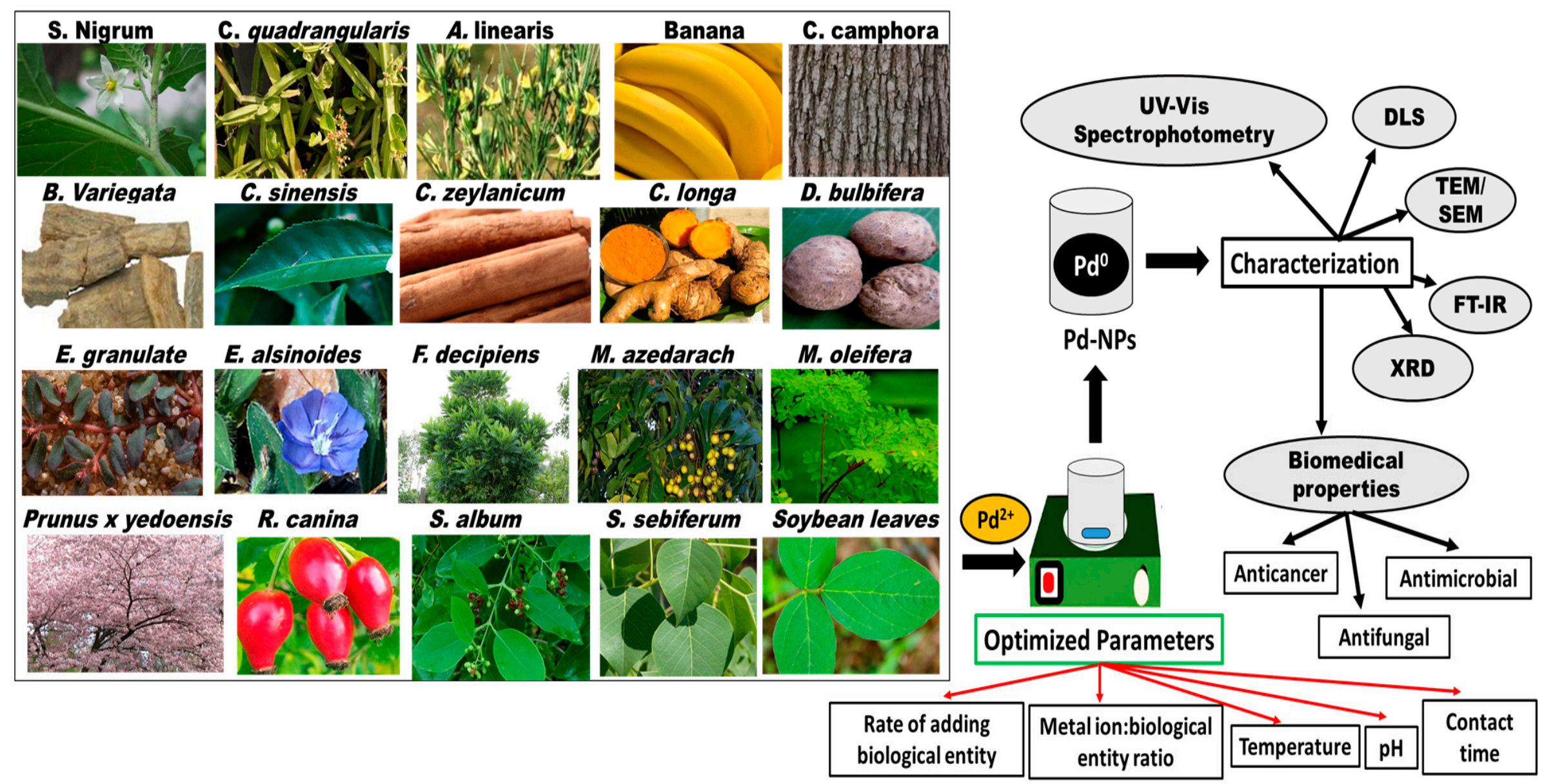

Figure 2. Schematic diagram summarizing the plant species employed in the bioreduction of Pd NPs, the parameters to be optimized, and the characterization of the fabricated nanoparticles. 
Table 1. Biosynthesis of Pd NPs using plant extracts.

\begin{tabular}{|c|c|c|c|c|c|c|}
\hline Plant & Part Used & $\begin{array}{c}\text { Conditions of the } \\
\text { Reaction } \\
\text { (Temperature, } \\
\text { Contact Time) }\end{array}$ & Average Size (nm) & Shape & $\begin{array}{l}\text { Biomedical } \\
\text { Properties }\end{array}$ & Reference \\
\hline Solanum nigrum & Leaf extract & $\begin{array}{l}\text { Room temperature. } \\
10 \mathrm{~min} .\end{array}$ & 21.55 & $\begin{array}{l}\text { Spherical and } \\
\text { polydispersed }\end{array}$ & $\begin{array}{l}\text { - Antibacterial } \\
\text { activity against } \\
\text { Escherichia coli }\end{array}$ & [25] \\
\hline Cissus quadrangularis & Stem extract & $\begin{array}{l}\text { Room temperature. } \\
10 \mathrm{~min} .\end{array}$ & $12-26$ & Spherical & $\begin{array}{l}\text { - } \\
\text { Antibacterial } \\
\text { activity against } \\
\text { Escherichia coli }\end{array}$ & [63] \\
\hline Aspalathus linearis & Leaf extract & $\begin{array}{l}\text { Room temperature. } \\
30 \mathrm{~min}\end{array}$ & 12.7 & $\begin{array}{l}\text { spherical, triangular, } \\
\text { rectangular, cubic, } \\
\text { and decahedron }\end{array}$ & & [64] \\
\hline Bauhinia variegata & Bark extract & $\begin{array}{l}\text { Hot centrifugation at } \\
6000 \mathrm{rpm} .10-15 \mathrm{~min} .\end{array}$ & $2-9$ & $\begin{array}{l}\text { Irregular shape } \\
\text { (cylindrical) and } \\
\text { highly aggregated }\end{array}$ & $\begin{array}{ll}\text { - } & \text { Potent } \\
\text { antibacterial } \\
\text { activity against } \\
\text { Gram-positive } \\
\text { bacteria (Bacillus } \\
\text { subtilis) } \\
\text { - } \\
\text { Significant } \\
\text { antifungal } \\
\text { activity against } \\
\text { Candida albicans } \\
\text { Potent } \\
\text { anticancer } \\
\text { activity against } \\
\text { MCF-7 breast } \\
\text { cancer cell lines }\end{array}$ & [65] \\
\hline $\begin{array}{l}\text { Camellia sinensis } \\
\text { (Lahijan Black tea) }\end{array}$ & Leaf extract & $\begin{array}{c}100{ }^{\circ} \mathrm{C} .1 \mathrm{~h} . \mathrm{Pd}(\mathrm{II}): \\
\text { leaf extract in ratio } \\
10: 1\end{array}$ & 7 & Spherical & & [66] \\
\hline
\end{tabular}


Table 1. Cont

\begin{tabular}{|c|c|c|c|c|c|c|}
\hline Plant & Part Used & $\begin{array}{c}\text { Conditions of the } \\
\text { Reaction } \\
\text { (Temperature, } \\
\text { Contact Time) }\end{array}$ & Average Size (nm) & Shape & $\begin{array}{c}\text { Biomedical } \\
\text { Properties }\end{array}$ & Reference \\
\hline $\begin{array}{l}\text { Camellia sinensis } \\
\text { (White tea) }\end{array}$ & Powder & $40^{\circ} \mathrm{C} .2 \mathrm{~h}$. & $6-18$ & Spherical & $\begin{array}{l}\text { Antibacterial } \\
\text { activities against } \\
\text { Staphylococcus } \\
\text { epidermidis and } \\
\text { Escherichia coli } \\
\text { Antioxidant and } \\
\text { free radical } \\
\text { scavenging activity } \\
\text { More anticancer } \\
\text { activity against } \\
\text { human leukemia } \\
\text { (MOLT-4) cells } \\
\text { compared to } \\
\text { doxorubicin } \\
\text { and cisplatin. }\end{array}$ & {$[6]$} \\
\hline $\begin{array}{l}\text { Cinnamomum } \\
\text { zeylanicum }\end{array}$ & Bark extract & $\begin{array}{c}30{ }^{\circ} \mathrm{C} .72 \mathrm{~h} . \text { Incubated } \\
\text { (dark) in a rotary } \\
\text { shaker at } 160 \mathrm{rpm} . \\
\mathrm{pH}>5\end{array}$ & $15-20$ & Crystalline & & [67] \\
\hline Curcuma longa & Tuber extract & $\begin{array}{c}30{ }^{\circ} \mathrm{C} .72 \mathrm{~h} . \text { Incubated } \\
\text { (dark) in a rotary } \\
\text { shaker at } 160 \mathrm{rpm} . \\
\mathrm{pH}>5\end{array}$ & $10-15$ & Spherical & & [68] \\
\hline $\begin{array}{l}\text { Cinnamomum } \\
\text { camphora }\end{array}$ & Leaf broth & $\begin{array}{c}30{ }^{\circ} \mathrm{C} .12 \mathrm{~h} . \text { Incubated } \\
\text { (dark) in a rotary } \\
\text { shaker at } 150 \mathrm{rpm}\end{array}$ & $3.2-6.0$ & $\begin{array}{c}\text { Quasi-spherical and } \\
\text { irregular }\end{array}$ & & [69] \\
\hline Coffee and tea extract & Powder & Room temperature. & $5-100$ & Spherical & & {$[70]$} \\
\hline
\end{tabular}


Table 1. Cont

\begin{tabular}{|c|c|c|c|c|c|c|}
\hline Plant & Part Used & $\begin{array}{c}\text { Conditions of the } \\
\text { Reaction } \\
\text { (Temperature, } \\
\text { Contact Time) }\end{array}$ & Average Size (nm) & Shape & $\begin{array}{l}\text { Biomedical } \\
\text { Properties }\end{array}$ & Reference \\
\hline Dioscorea bulbifera & Tuber extract & $100^{\circ} \mathrm{C} .5 \mathrm{~h}$ & $10-25$ & $\begin{array}{c}\text { Spherical and } \\
\text { blunt-ended cubes }\end{array}$ & $\begin{array}{l}\text { - } \\
\text { Anticancer } \\
\text { activity against } \\
\text { human cervical } \\
\text { (HeLa) } \\
\text { cancer cells } \\
\text { - } \quad \text { Antioxidant }\end{array}$ & [71] \\
\hline Euphorbia granulate & Leaf extract & $80^{\circ} \mathrm{C} .5 \mathrm{~min}$. & $25-30$ & & & [72] \\
\hline Evolvulus alsinoides & Leaf extract & $60^{\circ} \mathrm{C} .6 \mathrm{~h}$. & 5 & Spherical & $\begin{array}{l}\text { Anticancer } \\
\text { activity against } \\
\text { human ovarian } \\
\text { cancer } \\
\text { A2780 cells }\end{array}$ & [73] \\
\hline Filicium decipiens & Leaf extract & $\begin{array}{c}\text { Room temperature. } 4 \\
\text { d. }\end{array}$ & 6.36 & Spherical & 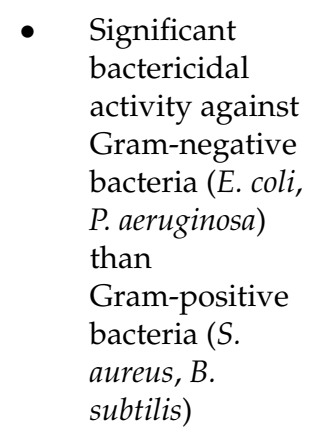 & [74] \\
\hline
\end{tabular}


Table 1. Cont.

\begin{tabular}{|c|c|c|c|c|c|c|}
\hline Plant & Part Used & $\begin{array}{c}\text { Conditions of the } \\
\text { Reaction } \\
\text { (Temperature, } \\
\text { Contact Time) }\end{array}$ & Average Size (nm) & Shape & $\begin{array}{c}\text { Biomedical } \\
\text { Properties }\end{array}$ & Reference \\
\hline Melia azedarach & Leaf extract & $100^{\circ} \mathrm{C} .20 \mathrm{~min}$. & $10-20$ & Spherical & $\begin{array}{l}\text { Antibacterial } \\
\text { activity against } \\
\text { Gram-positive } \\
\text { and } \\
\text { Gram-negative } \\
\text { bacterial strains } \\
\text { Larvicidal } \\
\text { activity against } \\
\text { Aedes aegypti }\end{array}$ & [75] \\
\hline Moringa oleifera & Flower extract & $25^{\circ} \mathrm{C} .1 \mathrm{~h}$. & $10-50$ & Spherical & $\begin{array}{l}\text { Cytotoxic } \\
\text { activity against } \\
\text { human lung } \\
\text { carcinoma cells } \\
\text { (A549) and } \\
\text { peripheral } \\
\text { lymphocytes } \\
\text { normal cells } \\
\text { Antioxidant and } \\
\text { free radical } \\
\text { scavenger. } \\
\text { Antibacterial } \\
\text { activity against } \\
\text { Enterococcusfaecalis }\end{array}$ & {$[76]$} \\
\hline
\end{tabular}


Table 1. Cont.

\begin{tabular}{|c|c|c|c|c|c|c|}
\hline Plant & Part Used & $\begin{array}{c}\text { Conditions of the } \\
\text { Reaction } \\
\text { (Temperature, } \\
\text { Contact Time) }\end{array}$ & Average Size $(\mathrm{nm})$ & Shape & $\begin{array}{l}\text { Biomedical } \\
\text { Properties }\end{array}$ & Reference \\
\hline Moringa oleifera & Peel extract & $\begin{array}{l}\text { Microwave } \\
\text { irradiation: } 300 \mathrm{~W} . \\
300^{\circ} \mathrm{C} .5 \mathrm{~min} .\end{array}$ & $27 \pm 2$ & Spherical & $\begin{array}{l}\text { More } \\
\text { antibacterial } \\
\text { activity against } \\
\text { S. aureus than } \\
\text { E. coli } \\
\text { - Nontoxic to red } \\
\text { blood cells } \\
\text { (RBCs) }\end{array}$ & [77] \\
\hline Prunus $\times$ yedoensis & Leaves extract & $\begin{array}{c}80{ }^{\circ} \mathrm{C} .30 \mathrm{~min} . \mathrm{pH} 7 . \\
\mathrm{Pd}(\mathrm{II}): \text { leaf extract in } \\
\text { ratio } 40: 5\end{array}$ & $50-150$ & Spherical & $\begin{array}{l}\text { - Significant } \\
\text { antibacterial } \\
\text { activity against } \\
\text { Bacillus subtilis } \\
\text { and } \\
\text { Pseudomonas aeruginosa }\end{array}$ & {$[78]$} \\
\hline Rosa canina & Fruit extract & $100^{\circ} \mathrm{C} .2 \mathrm{~h}$ & $10 \pm 3$ & Spherical & & [79] \\
\hline Santalum album & Leaf extract & $\begin{array}{l}\text { Room temperature. } 4 \\
\text { d. Pd (II): leaf extract } \\
\text { in ratio 9:1 }\end{array}$ & $10-40$ & Spherical & $\begin{array}{l}\text { More } \\
\text { bactericidal } \\
\text { activity against } \\
\text { Escherichia coli } \\
\text { and } \\
\text { Pseudomonas } \\
\text { aeruginosa than } \\
\text { Bacillus subtilis } \\
\text { and } \\
\text { Staphylococcus aureus. }\end{array}$ & [80] \\
\hline
\end{tabular}


Table 1. Cont

\begin{tabular}{|c|c|c|c|c|c|c|}
\hline Plant & Part Used & $\begin{array}{c}\text { Conditions of the } \\
\text { Reaction } \\
\text { (Temperature, } \\
\text { Contact Time) }\end{array}$ & Average Size (nm) & Shape & $\begin{array}{c}\text { Biomedical } \\
\text { Properties }\end{array}$ & Reference \\
\hline Sapium sebiferum & Leaf extract & $\begin{array}{l}100^{\circ} \mathrm{C} \text {. Magnetic } \\
\text { stirring in the dark }\end{array}$ & $2-5$ & Spherical & $\begin{array}{l}\text { Enhanced } \\
\text { bactericidal } \\
\text { activity against } \\
\text { Staphylococcus } \\
\text { aureus, Bacillus } \\
\text { subtilis, and } \\
\text { Pseudomonas aeruginosa }\end{array}$ & 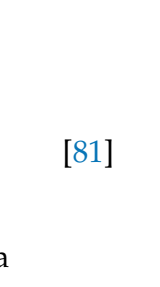 \\
\hline $\begin{array}{c}\text { Glycine max (Soya } \\
\text { bean) }\end{array}$ & Leaf extract & $\begin{array}{c}2 \text { d. Pd (II): leaf } \\
\text { extract in ratio 20:1 }\end{array}$ & $\sim 15$ & Spherical & & [82] \\
\hline Rosmarinus officinalis & Leaf extract & $\begin{array}{l}\text { Room temperature. } \\
\qquad 24 \mathrm{~h}\end{array}$ & $15-90$ & $\begin{array}{l}\text { Semi-spherical and } \\
\text { polyhedral }\end{array}$ & $\begin{array}{l}\text { - Acceptable } \\
\text { antibacterial } \\
\text { activity against } \\
\text { S. aureus, E. coli, } \\
\text { S. epidermidis, } \\
\text { and M. luteus } \\
\text { - Antifungal } \\
\text { activity against } \\
\text { C. parapsilosis, } \\
\text { C.albicans, C. } \\
\text { glabrata, and } \\
\text { C. krusei }\end{array}$ & [83] \\
\hline
\end{tabular}


Phytosynthesis of spherical Pd NPs with an average size of $21.55 \mathrm{~nm}$ was performed using Solanum nigrum leaf extract [25]. The palladium (II) ions were stirred with the leaf extract for $10 \mathrm{~min}$ at room temperature. The disappearance of the UV/Vis absorption spectrum at a peak range of $370-440 \mathrm{~nm}$ corresponding to Pd (II) ions suggested the reduction of Pd (II) [25]. The biosynthesized Pd NPs exhibited significant bactericidal activity against Escherichia coli (zone of inhibition: 18 and $19 \mathrm{~mm}$, respectively) [25]. Phytosynthesis of Pd NPs using Cissus quadrangularis stem extract involved the same preparation conditions [63]. The biosynthesized nanoparticles were spherical with an average size range of $12-26 \mathrm{~nm}$. The formation of Pd NPs was confirmed by the disappearance of the UV/Vis absorption spectrum at $420 \mathrm{~nm}$, corresponding to Pd (II) ions [63]. Pd NPs prepared by Cissus quadrangularis stem extract also showed remarkable antibacterial activity against E. coli at certain concentrations [63]. In another study, Aspalathus linearis leaf extract was stirred with the Pd (II) ions for $30 \mathrm{~min}$ at room temperature, then dried [64]. The formation of Pd NPs was initially confirmed qualitatively by the conversion of the initial solution color from light yellow to dark brown. The disappearance of the sharp UV/Vis absorption peak at $284.5 \mathrm{~nm}$ corresponding to Aspalathus linearis leaf extract and the appearance of an absorption continuum, characteristic for the reduced Pd NPs because of the surface plasmon resonance, confirmed the formation of the nanoparticles [64]. TEM investigations showed spherical, triangular, rectangular, cubic, and decahedron nanoparticles with an average size of $12.7 \mathrm{~nm}$ [64].

Vaghela et al. [65] reported the biosynthesis of Pd NPs using Bauhinia variegate bark extract. Cylindrical Pd NPs were observed with average size from 2 to $9 \mathrm{~nm}$ after hot centrifugation at $6000 \mathrm{rpm}$ for 10-15 min [65]. The disappearance of the UV/Vis absorption spectrum observed at $420 \mathrm{~nm}$, corresponding to Pd (II) ions, confirmed the generation of Pd NPs [65]. The phytosynthesized Pd NPs have shown to have potent antibacterial activity against the Gram-positive bacteria, Bacillus subtilis, and antifungal activity against Candida albicans. The nanoparticles have also shown potent cytotoxic activity against MCF-7 breast cancer cells (IC50: $18.34 \mu \mathrm{g} / \mathrm{mL}$ ) [65]. Lebasch et al. [66] developed an eco-friendly and facile method to biosynthesize Pd NPs using Camellia sinensis leaves extract. The biosynthesized Pd NPs, having an average size of $7 \mathrm{~nm}$ and spherical morphology, were prepared by the dropwise addition of leaves extract to Pd (II) ions solution (1:10) and heating at $100{ }^{\circ} \mathrm{C}$ for $1 \mathrm{~h} \mathrm{[66]}$. The disappearance of the UV/Vis absorption spectrum observed at $400 \mathrm{~nm}$ corresponding to Pd (II) ions suggested the reduction of Pd (II) ions and the creation of Pd NPs [66]. Azizi et al. [6] reported the phytosynthesis of spherical Pd NPs with an average size range of $6-18 \mathrm{~nm}$, mediated by Camellia sinensis (white tea) extract [6]. The palladium (II) ions were continuously stirred with the white tea extract (1:1) for $2 \mathrm{~h}$ at $40^{\circ} \mathrm{C}$ and the $\mathrm{pH}$ was found to be decreased from 7.5 to 5.6 (after the reaction). The typical peak of Pd (II) ions observed at $410 \mathrm{~nm}$ disappeared after the bioreduction accompanied by the appearance of a broad absorption continuum indicating the production of the Pd NPs [6]. The biosynthesized nanoparticles showed significant antioxidant effect and bactericidal activity against Staphylococcus epidermidis and Escherichia coli at minimum inhibitory concentrations of $0.15 \mu \mathrm{M}$ and $0.313 \mu \mathrm{M}$ (zone of inhibition: 17 and $14 \mathrm{~mm}$, respectively) [6]. Moreover, the Pd NPs mediated by white tea was found to possess a more potent anticancer activity toward human leukemia (MOLT-4) cells compared to cisplatin and doxorubicin (IC50: $0.006 \mu \mathrm{M}, 0.894 \mu \mathrm{M}$, and $2.133 \mu \mathrm{M}$, respectively), and no cytotoxic effect was observed on the normal human fibroblasts [6]. Sathishkumar et al. [67] obtained crystalline Pd NPs of 15-20 nm average size range using Cinnamomum zeylanicum bark extract, which was incubated with the Pd (II) ions solution in a rotary shaker at $160 \mathrm{rpm}$ in the dark at $30^{\circ} \mathrm{C}$ and $\mathrm{pH}>$ 5 for $72 \mathrm{~h}$ [67]. The same procedure was used to produce spherical Pd NPs mediated by Curcuma longa tuber extract of an average size range of 10-15 nm [68]. In another study, Cinnamomum camphora leaf broth was used to prepare quasi-spherical and irregular Pd NPs of an average size of 3.2-6 nm [69]. The leaf broth was incubated in the dark with the Pd (II) ions solution in a rotary shaker at $150 \mathrm{rpm}$ in the dark at $30^{\circ} \mathrm{C}$ for $12 \mathrm{~h}$ [69]. The formation of Pd NPs mediated by Cinnamomum camphora leaf broth was confirmed by the disappearance of the original UV/Vis peak of Pd (II) ions, observed above $300 \mathrm{~nm}$, and the appearance of new broad absorption continuum in the visible-near-ultraviolet region [69]. 
Nadagouda et al. [70] developed a simple method for the bulk green production of Pd NPs using coffee and tea powder extracts. The spherical nanoparticles with size range of 5-100 nm were prepared by simple mixing of the metal ions with the powder extracts and confirmed by the appearance of a characteristic broad UV/Vis continuum in the range of 200-1200 nm [70]. Ghosh et al. [71] employed the tuber extract of Dioscorea bulbifera to generate spherical and blunt-ended cubical Pd NPs of an average size range of $10-25 \mathrm{~nm}$ by conducting the bio-reaction at $100{ }^{\circ} \mathrm{C}$ for $5 \mathrm{~h}$ [71]. The UV/Vis observation showed disappearance of peak at $420 \mathrm{~nm}$, particularly to $\mathrm{Pd}$ (II) ions and higher absorbance compared to Pd NPs alone, indicating the formation of Pd NPs [71]. Pd NPs exhibited anticancer activity (33\%) against human cervical (HeLa) cancer cells [71]. Nasrollahzadeh et al. [72] reported the use of Euphorbia granulate leaf extract to prepare spherical Pd NPs of an average size range of 25-35 nm [72]. The nanoparticles were generated via the dropwise addition of leaf extract to $\mathrm{Pd}(\mathrm{II})$ ions while stirring at $120^{\circ} \mathrm{C}$ for $5 \mathrm{~min}$ [72]. A characteristic absorption spectrum appeared at 260-320 nm due to the formation of dark brown colored Pd NPs [72]. The nanoparticles were stable for up to one week [72]. Gurunathan et al. [73] prepared spherical Pd NPs (5 nm) using Evolvulus alsinoides leaf extract as the reducing agent and investigated their anticancer activity against human ovarian cancer cells (A2780 cells) [73]. The green synthesis was conducted at $60^{\circ} \mathrm{C}$ for $6 \mathrm{~h}$, and the formation of Pd NPs was confirmed by the disappearance of the first peak of Pd (II) ions observed at $417 \mathrm{~nm}$ and the appearance of a broad absorption continuum [73]. The prepared nanoparticles were found to have significant cytotoxic activity on A2780 cancer cells at doses higher than $6 \mu \mathrm{g} / \mathrm{mL}$ after $24 \mathrm{~h}$ of incubation, suggesting their potential use in cancer therapy [73]. Spherical Pd NPs $(6.36 \mathrm{~nm})$ were fabricated using the leaf extract of Filicium decipiens at room temperature and contact duration of $2 \mathrm{~d}$ [74]. UV/Vis absorbance peak due to phytometabolites was observed between 650-700 nm [74]. The phytosynthesized nanoparticles were found to have pronounced bactericidal activity against both Gram-positive and Gram-negative bacteria. However, this antibacterial effect was found to be higher against Escherichia coli and Pseudomonas aeruginosa (zone of inhibition: 27 and $24 \mathrm{~mm}$, respectively) in comparison to Staphylococcus aureus and Bacillus subtilis (zone of inhibition: $12 \mathrm{~mm}$ for both bacteria) making them promising cheap antibacterial candidates [74]. Bhakyaraj et al. [75] reported on the rapid biosynthesis of Pd NPs employing Melia azedarach leaf extract. The biogenic synthesis was achieved by stirring the leaf extract with the Pd (II) ions at $100^{\circ} \mathrm{C}$ for $20 \mathrm{~min}$. The generated spherical Pd NPs had an average size range of 10-20 nm, and their formation was confirmed by the appearance of $\mathrm{UV} /$ Vis absorbance peak at $280 \mathrm{~nm}$, which is characteristic to the surface plasmon resonance of $\mathrm{Pd}$ NPs [75]. The biosynthesized Pd NPs exhibited significant bactericidal activity against Gram-positive and Gram-negative bacteria (the inhibition zones for B. subtilis $=8.33 \pm 0.33 \mathrm{~mm}$; for S. aureus, E. coli, and P. vulgaris $=7.33 \pm 0.33 \mathrm{~mm}$; and for Streptococcus pneumoniae and P. aeruginosa $=5.33 \pm 0.33 \mathrm{~mm}$ ) [75]. In addition, the Pd NPs prepared using Melia azedarach leaf extract showed significant larvicidal activity against larvae of Aedes aegypti (LC50 $=27.36 \%$; LC90 52.50\%) [75]. Two studies reported on the green synthesis of Pd NPs using Moringa oleifera flower and peel extracts yielding spherical nanoparticles with sizes $10-50$ and $27 \mathrm{~nm}$, respectively [76,77]. The first synthesis was achieved at $25^{\circ} \mathrm{C}$ for $1 \mathrm{~h} \mathrm{[76],} \mathrm{while}$ the second one was completed at $300^{\circ} \mathrm{C}$ for $5 \mathrm{~min}$ incubation employing microwave irradiation [77]. Both studies used a variety of techniques to study the prepared Pd NPs such as FT-IR, XRD, TGA, SEM, and TEM but employed the UV/Vis spectroscopy as an extra tool to confirm the production of Pd NPs [76,77]. In the first study conducted by Anand et al. [76], a strong, surface plasmon resonance was observed in the absorption spectrum at $460 \mathrm{~nm}$, which indicated the formation of Pd NPs [76]. The biosynthesized Pd NPs showed anticancer activity against human lung cancer cells (A549) without inducing any toxicity toward peripheral lymphocytes normal cells. The nanoparticles also exhibited antioxidant effects and bactericidal activity against Enterococcus faecalis [76]. In the second study conducted by Surendra et al. [77], the phytosynthesized Pd NPs showed pronounced antibacterial activity against Staphylococcus aureus, and Escherichia coli and the inhibition zones were found out to be $0.7 \mathrm{~mm}$ and $0.6 \mathrm{~mm}$, respectively [58]. The nanoparticles showed no toxicity (hemolysis) when tested 
on red blood cells [77]. Both studies support the potential of using Pd NPs mediated by Moringa oleifera as possible safe and effective antibacterial and anticancer therapeutic agents.

Manikandan et al. demonstrated the synthesis of spherical Pd NPs (50-150 nm) using leaves extract of Prunus $\times$ yedoensis [78]. The eco-friendly method was conducted by the continuous stirring of Pd (II) and leaf extract in ratio $40: 5$ at $80{ }^{\circ} \mathrm{C}$ and $\mathrm{pH} 7$ for $30 \mathrm{~min}$. The appearance of a UV/Vis absorption spectrum at $421 \mathrm{~nm}$ indicated the formation of Pd NPs. The generated nanoparticles exhibited bactericidal activity against Bacillus subtilis $(6 \mathrm{~mm})$ and Pseudomonas aeruginosa $(5 \mathrm{~mm})$ at a concentration of $250 \mu \mathrm{g} / \mathrm{mL}$ [78]. A study conducted by Veisi et al. reported on the facile green synthesis of Pd NPs employing the fruit extract of Rosa canina [79]. The biosynthesis was carried out at $100{ }^{\circ} \mathrm{C}$ for $2 \mathrm{~h}$ using acetone as anti-solvent, and the average size of biosynthesized spherical Pd NPs was found to be $10 \mathrm{~nm}$ [79]. The disappearance of the UV/Vis absorption spectrum observed at $418 \mathrm{~nm}$ corresponding to Pd (II) ions suggested the reduction of Pd (II) ions and the generation of Pd NPs [79].

Two recent studies reported on the efficient biosynthesis of Pd NPs involving the leaves extract of the Santalum album [80] and Sapium sebiferum [81]. The Pd NPs generated using the leaf extract of Santalum album were prepared by mixing Pd (II) ions with the leaf extract in ratio 9:1 at room temperature for $4 \mathrm{~d}$ [80]. The produced spherical nanoparticles had an average size range of 10-40 nm. They showed potent antibacterial activity against Gram-negative bacteria (E. coli, $31 \mathrm{~mm}$; P. aeruginosa, $30 \mathrm{~mm}$ ) which was higher than Gram-positive bacteria (B. subtilis, $12 \mathrm{~mm}$; S. aureus $18 \mathrm{~mm}$ ) [80]. The Pd NPs produced by the leaf extract of Sapium sebiferum were prepared by stirring Pd (II) ions with the leaf extract in the dark at $100{ }^{\circ} \mathrm{C}$ [81]. The produced spherical nanoparticles had an average size range of 2-5 nm and exhibited significant bactericidal activity against Staphylococcus aureus $29( \pm 0.8 \mathrm{~mm})$, Bacillus subtilis $19( \pm 0.6 \mathrm{~mm})$, and Pseudomonas aeruginosa $11( \pm 0.6 \mathrm{~mm})$ [81]. The disappearance of the peak observed at $420-440 \mathrm{~nm}$ corresponding to Pd (II) ions suggests the formation of Pd NPs in the first study [80]. While the appearance of the surface plasmon resonance peak at $274 \mathrm{~nm}$ indicates the generation of Pd NPs in the second study [81].

A study conducted by Petla et al. reported on the phytosynthesis of spherical Pd NPs of $\sim 15 \mathrm{~nm}$ average size using protein-rich soybean leaf extract by mixing Pd (II) ionic solution with the leaf extract in ratio 20:1 for two days [82]. As for the rest of the studies reported on the green synthesis of Pd NPs using plant extracts, the generation of the Pd NPs was confirmed by the disappearance of the UV/Vis absorption spectrum observed at $420 \mathrm{~nm}$ corresponding to Pd (II) ions [82]. Finally, the green synthesis of Pd NPs employing the leaf extract of Rosmarinus officinalis was recently reported [83]. The generated Pd NPs were prepared by mixing Pd (II) ions with the leaf extract at room temperature for $24 \mathrm{~h}$ [83]. The produced semi-spherical and polyhedral nanoparticles had an average size range of $15-90 \mathrm{~nm}$. The appearance of the standard UV/Vis absorption spectrum of Pd NPs in the range of 200-240 nm suggested the generation of Pd NPs [83]. The biosynthesized Pd NPs exhibited acceptable antibacterial activity against Staphylococcus aureus $(46.7 \mathrm{~mm})$, E. coli $(18.0 \mathrm{~mm})$, Staphylococcus epidermidis $(39.5 \mathrm{~mm})$, and Micrococcus luteus (41.2 mm) at a concentration of $10 \mu \mathrm{g} / \mathrm{mL}$. Additionally, the created Pd NPs showed antifungal activity against Candida parapsilosis (19.4 mm), Candida albicans $(8.5 \mathrm{~mm})$, Candida glabrata $(97.1 \mathrm{~mm})$, and Candida krusei $(21.8 \mathrm{~mm})$ [83].

\section{Other Biological Systems for the Pd NPs Biosynthesis}

Ascorbic acid (as reducing agent) and sodium alginate (a stabilizing agent from brown algae) were mixed with the Pd (II) ions, and then heated in a microwave oven $(850 \mathrm{~W})$ for $3 \mathrm{~min}$. The formation of Pd NPs was confirmed qualitatively by the conversion of the solution light yellow color into a dark brown color, and quantitatively by UV/Vis spectrophotometry [84]. A broad continuous absorption band at $345 \mathrm{~nm}$ was observed, with the disappearance of the $\operatorname{Pd}(\mathrm{II})$ ions original band at $441 \mathrm{~nm}$. This indicates the bioreduction of Pd (II) ions to Pd NPs. The generated spherical Pd NPs had a size range of 13-33 nm [84]. The biosynthesized Pd NPs exhibited significant anticancer activity against A4549 lung cancer cells ( $48 \mathrm{~h}$ treatment) compared to Pd (II) acetate and cisplatin anticancer drugs. Additionally, the produced Pd NPs showed a pronounced antioxidant activity compared to Pd (II) acetate when the 
DPPH scavenging activity assay was conducted. The scavenging activities were $32.9 \pm 3.2 \%$ and $27.2 \pm$ $2.1 \%$ for Pd (II) acetate and Pd NPs, respectively, at a concentration of $640 \mu \mathrm{g} / \mathrm{mL}$ [84].

A recent study reported the green synthesis of multifunctional and spherical Pd NPs employing Agaricus bisporus (mushroom) fungi [85]. The NPs were generated by mixing the mushroom with Pd (II) ions in a ratio of 1:9 at room temperature until a brown color is developed, indicating the formation of Pd NPs. The formation of Pd NPs was confirmed by the disappearance of the UV/Vis absorption spectrum observed at $405 \mathrm{~nm}$, corresponding to Pd (II) ions [85]. The prepared Pd NPs were stable (a zeta potential of $-24.3 \mathrm{mV}$ ) and $13 \mathrm{~nm}$ in size. They exhibited significant bactericidal activity against the Gram-positive Streptococcus pyogenes $(16 \pm 1.5 \mathrm{~mm})$ and the Gram-negative Enterobacter aerogenes $(21 \pm 0.5 \mathrm{~mm})$ [85]. Additionally, the NPs were found to have remarkable anticancer activity against PK13 kidney cancer cells. The maximum cell growth inhibition (30\%) was observed at $50 \mu \mathrm{g} / \mathrm{mL}$ after $36 \mathrm{~h}$ (IC50: $26.1 \mu \mathrm{g} / \mathrm{mL}$ ) [85]. Furthermore, the produced NPs were found to possess antioxidant and anti-inflammatory activities and biocompatibility with red blood cells [85].

Another recent study reported on the rapid biosynthesis of Pd NPs with controllable size and shape and reduced reaction time using the urine of the indigenous Indian Khilar cow [86]. The NPs were prepared by the dropwise addition of cow urine to $\mathrm{Pd}$ (II) ions with continuous stirring at $80^{\circ} \mathrm{C}$ and physiological $\mathrm{pH}$ [86]. The appearance of a UV/Vis peak at $410 \mathrm{~nm}$ suggests the synthesis of $\mathrm{Pd}$ NPs. Field emission scanning electron microscopy showed the generation of cylindrical, polydispersed Pd NPs. The biosynthesized NPs exhibited good antibacterial activities against E. coli (15 mm), Bacillus cereus $(15 \mathrm{~mm})$, P. aeruginosa $(16 \mathrm{~mm})$, and S. typhi $(16 \mathrm{~mm})$ at a concentration of $200 \mu \mathrm{g} / \mathrm{mL}$ [86]. At the same concentration, Pd NPs prepared by cow urine were found to have antifungal activity against Aspergillus niger $(12 \mathrm{~mm})$ and Fusarium solani $(11 \mathrm{~mm})$. Pd NPs also showed good antioxidant activity, compared to standard ascorbic acid, where the radical scavenging activity (using DPPH assay) was found to be $28 \%$ [86].

Arsiya et al. [87] created an eco-friendly and rapid procedure for the biosynthesis of stabilized, monodispersed, and spherical Pd NPs of an average size of $15 \mathrm{~nm}$, employing Chlorella vulgaris marine algae. The marine algae were stirred with $\mathrm{Pd}$ (II) ions at $60^{\circ} \mathrm{C}$ for $10 \mathrm{~min}$ and then kept in the dark [87]. The typical peak of Pd (II) ions observed at 410-420 nm disappeared after the bioreduction was accompanied by the appearance of a broad absorption continuum at a range of $370-440 \mathrm{~nm}$, indicating the production of the Pd NPs [87]. Finally, the marine algae Sargassum bovinum was exploited for the rapid and cost-effective green synthesis of monodispersed, octahedral Pd NPs of an average size of $5 \mathrm{~nm}$ [88]. The marine algae were mixed with Pd (II) ions in a rotary shaker at $160 \mathrm{rpm}$ for $24 \mathrm{~h}$, and the temperature was kept at $60{ }^{\circ} \mathrm{C}$. The disappearance of the absorption peaks above $300 \mathrm{~nm}$, related to Pd (II) ions in the UV/Vis spectrum of Pd NPs, indicated the bioreduction of Pd (II) ions and the formation of Pd NPs. Additionally, a broad absorption band appeared and extended throughout the visible-near-ultraviolet region [88]. These findings are summarized in Table 2.

Various techniques are employed in the confirmation of Pd NPs generation, such as Fourier transform infrared spectroscopy (FT-IR), X-ray diffraction (XRD), transmission electron microscopy (TEM), scanning electron microscopy (SEM), dynamic lights scattering (DLS), and thermal gravimetric analysis (TGA) [61]. However, UV/Vis spectrophotometry and TEM provide a convenient way to confirm the production of Pd NPs (Figure 3). Table 3 summarizes the UV/Vis absorption spectra of the Pd NPs biosynthesized using different biological sources. 
Table 2. Biosynthesis of Pd NPs using various biological entities.

\begin{tabular}{|c|c|c|c|c|c|c|}
\hline $\begin{array}{c}\text { Biological } \\
\text { Entity }\end{array}$ & Type & $\begin{array}{c}\text { Conditions of } \\
\text { Synthesis } \\
\text { (Temperature, } \\
\text { Contact Time) }\end{array}$ & $\begin{array}{c}\text { Average } \\
\text { Size (nm) }\end{array}$ & Shape & Biomedical Properties & Ref. \\
\hline $\begin{array}{l}\text { Sodium } \\
\text { alginate }\end{array}$ & Brown algae & $3 \mathrm{~min}$ & $13-33$ & spherical & $\begin{array}{ll}\text { - } & \text { Anticancer activity against } \\
\text { - } & \text { A4549 lung cancer cells } \\
\text { - } & \text { Antioxidant } \\
\text { - } & \text { Antifungal }\end{array}$ & [84] \\
\hline $\begin{array}{c}\text { Agaricus } \\
\text { bisporus }\end{array}$ & $\begin{array}{l}\text { Mushroom } \\
\text { (fungi) }\end{array}$ & Room temperature & 13 & Spherical & $\begin{array}{ll}\text { - } & \text { Anticancer activity against } \\
\text { - } & \text { BK13 kidney cancer cells } \\
\text { - } & \text { Antioxidant activity } \\
\text { - } & \text { Anti-inflammatory } \\
\text { - } & \text { Biocompatible to RBCs }\end{array}$ & [85] \\
\hline $\begin{array}{l}\text { Indian } \\
\text { Khilar cow } \\
\text { urine }\end{array}$ & & $80^{\circ} \mathrm{C}$ & - & Cylindrical & $\begin{array}{ll}\text { - } & \text { Antioxidant } \\
\text { - } & \text { Antibacterial } \\
\text { - } & \text { Antifungal }\end{array}$ & [86] \\
\hline $\begin{array}{l}\text { Chlorella } \\
\text { vulgaris }\end{array}$ & Marine algae & $60^{\circ} \mathrm{C} 10 \mathrm{~min}$ & 15 & Spherical & & [87] \\
\hline $\begin{array}{l}\text { Sargassum } \\
\text { bovinum }\end{array}$ & Marine algae & $60^{\circ} \mathrm{C} 24 \mathrm{~h}$ & 5 & Octahedral & & [88] \\
\hline
\end{tabular}

Table 3. UV/Vis absorption spectra for biosynthesized Pd NPs.

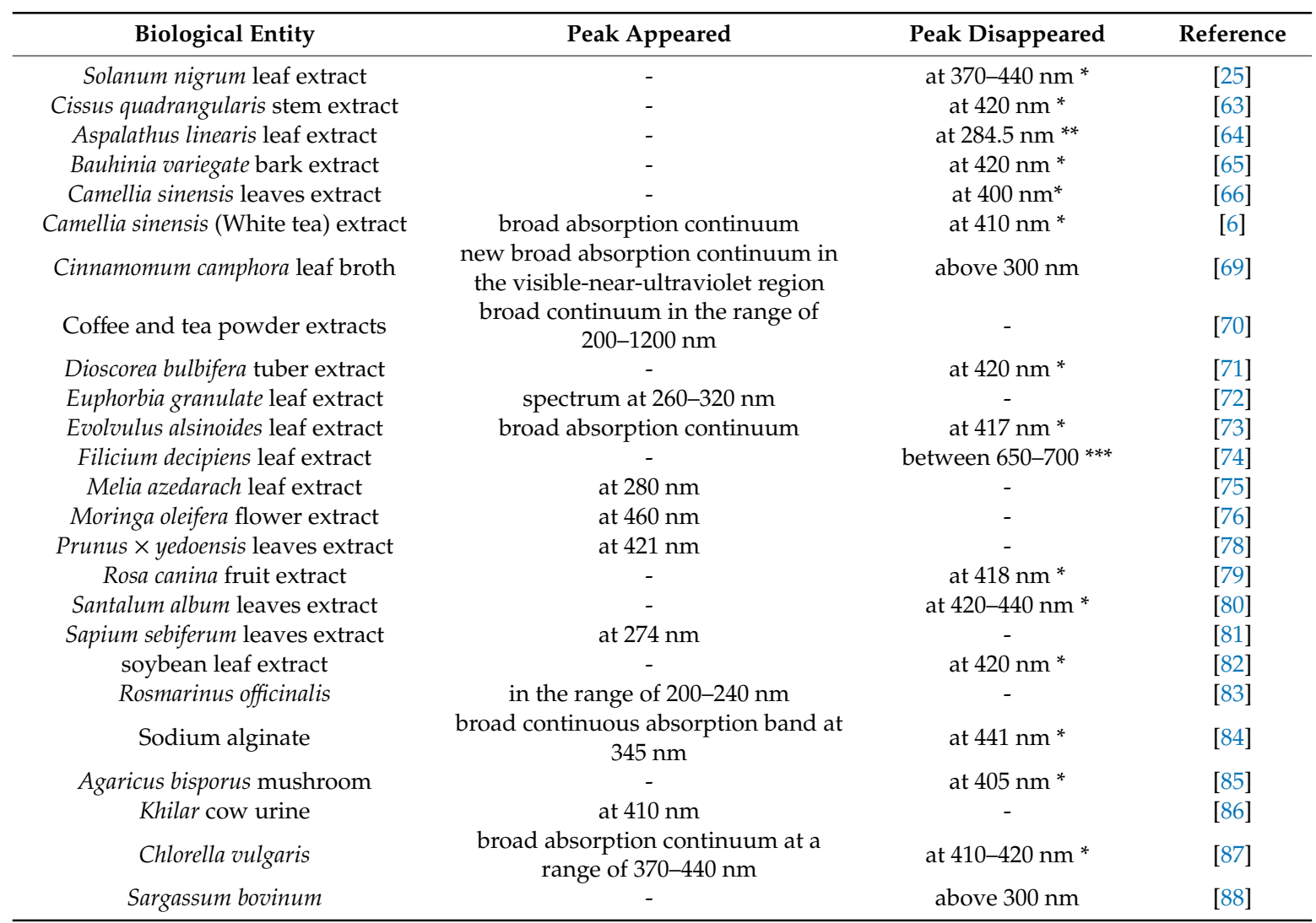

* corresponding to Pd (II) ions. ** corresponding to Aspalathus linearis leaf extract. ${ }^{* * *}$ corresponding to phytometabolites. 

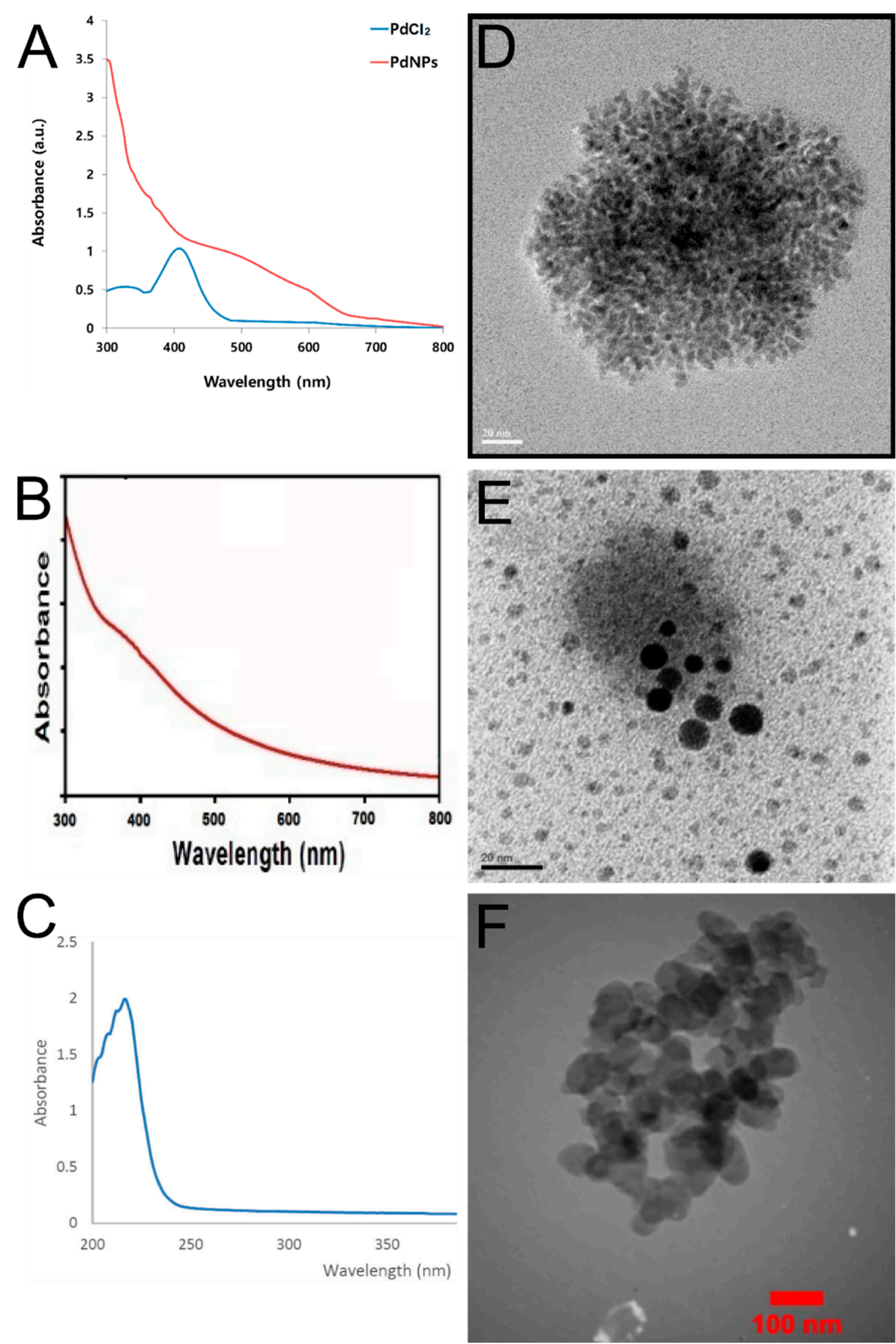

Figure 3. Characterization of Pd NPs biosynthesized by different plant extracts using UV/Vis spectrophotometry and TEM. (A-C) are the UV/Vis spectra of the biosynthesized Pd NPs using Evolvulus alsinoides, Solanum nigrum, and Rosmarinus officinalis, respectively. (D-F) are the TEM images of the biosynthesized Pd NPs using Evolvulus alsinoides, Solanum nigrum, and Rosmarinus officinalis, respectively. $[25,73,83]$. 


\section{Biosynthesis of Pd Bimetallic NPs}

Few studies reported the biosynthesis of Pd bimetallic NPs. Spherical platinum-palladium (Pt-Pd) NPs (10-25 nm) were biosynthesized using the tuber extract of Dioscorea bulbifera [71]. Pt-Pd NPs exhibited a remarkable anticancer activity $(74 \%)$ against human cervical (HeLa) cancer cells compared to Pd NPs (33\%) and Pt NPs (12.6\%) alone [71].

Another study reported the green synthesis of spherical gold-palladium ( $\mathrm{Au}-\mathrm{Pd}) \mathrm{NPs}(7 \mathrm{~nm})$, using Cacumen platycladi leaf extract in aqueous medium [89]. The Au NPs exhibited a characteristic surface plasmon resonance (SPR) peak at $531 \mathrm{~nm}$, while no peak was observed for the Pd NPs [89]. A study conducted by Luo et al. reported the facile biosynthesis of iron-palladium (Fe-Pd) NPs utilizing the aqueous leaf extract of grape [90]. The size range of the biosynthesized quasi-spherical Au-Pd NPs was 10-100 nm [90]. A recent study reported the green synthesis of spherical silver-palladium (Ag-Pd) NPs employing aqueous fruit extract of Terminalia chebula [91]. The bimetallic NPs were generated by the dropwise addition of the fruit extract to silver nitrate solution followed by stirring for $10 \mathrm{~min}$. Then, Pd (II) chloride was added, followed by stirring for $1 \mathrm{~h}$ at room temperature. The formation of Ag-Pd NPs was confirmed by the appearance of Ag NPs UV/Vis peak at $420 \mathrm{~nm}$ [91]. The prepared Pd NPs were stable (zeta potential of $-14.4 \mathrm{mV}$ ) and were $20 \mathrm{~nm}$ in size. They exhibited significant bactericidal activity against Gram-positive MRSA $11(12 \mathrm{~mm})$, Gram-positive MRSA $56(14 \mathrm{~mm})$, and the Gram-negative P. aeruginosa $(16 \mathrm{~mm})$ at a concentration of $30 \mu \mathrm{g} / \mathrm{mL}$ [91]. Additionally, the bimetallic NPs were found to have remarkable anticancer activity against A549 cancer cells with IC50 of $48.45 \mu \mathrm{g} / \mathrm{mL}$ compared to cisplatin anticancer drug (IC50 $18.09 \mu \mathrm{g} / \mathrm{mL}$ ) [91].

The biosynthesis of Pd NPs mediated by different biological entities are influenced by factors such as temperature, reaction time, the ratio of metal ions to plant extract, and $\mathrm{pH}$. These factors control not only the production process of the Pd NPs, but also their sizes, shapes, and stability. For instance, smaller Pd NPs are formed at higher $\mathrm{pH}$, while larger Pd NPs are formed at lower $\mathrm{pH}$. Furthermore, increasing the reaction temperature could increase the yield of Pd NPs, rate of the reaction, and surface plasmon resonance. Thus, these factors should be carefully optimized to produce optimized and therapeutically active Pd NPs.

\section{Conclusions}

Plant extracts and other biological entities have been used for the biosynthesis of Pd NPs. Biosynthesis conditions such as $\mathrm{pH}$, temperature, and reaction time must be optimized as they influence the size, shape, and stability of the prepared metallic nanoparticles. Plants and other biological entities are rich in diverse metabolites, making them excellent candidates for the bioreduction of palladium salts into Pd NPs. Few studies reported synthesis of Pd NPs using algae and microbes with the aim of biomedical applications. Pd NPs mediated by the biological systems showed various biomedical applications including bactericidal activity against Gram-negative and Gram-positive bacteria, antifungal, antioxidant, and anticancer activities against various cancer cells derived from lung, cervical, ovarian, and breast cancers. Pd NPs capped with plant extracts are nontoxic and biocompatible compared to platinum-based anticancer drugs such as cisplatin, carboplatin, and oxaliplatin. Moreover, biosynthesized Pd NPs were found to possess more enhanced anticancer activities compared to other synthetic anticancer drugs. These findings may lead to the development of novel anticancer and antibacterial drugs which are safe, eco-friendly, and more effective in comparison to their synthetic counterparts.

Author Contributions: Conceptualization, S.A.F., U.B., and H.M.E.-S.A.; methodology, S.A.F. and E.P.; data curation, S.A.F. and E.P.; writing—original draft preparation, S.A.F.; writing-review and editing, S.A.F., E.P., U.B., and H.M.E.-S.A.; supervision, U.B. and H.M.E.-S.A.; project administration, U.B. and H.M.E.-S.A. All authors have read and agreed to the published version of the manuscript.

Funding: This research received no external funding.

Conflicts of Interest: The authors declare no conflict of interest. 


\section{References}

1. Chen, A.; Ostrom, C. Palladium-Based Nanomaterials: Synthesis and Electrochemical Applications. Chem. Rev. 2015, 115, 11999-12044. [CrossRef] [PubMed]

2. Saldan, I.; Semenyuk, Y.; Marchuk, I.; Reshetnyak, O. Chemical synthesis and application of palladium nanoparticles. J. Mater. Sci. 2015, 50, 2337-2354. [CrossRef]

3. Bharathiraja, S.; Bui, N.Q.; Manivasagan, P.; Moorthy, M.S.; Mondal, S.; Seo, H.; Phuoc, N.T.; Vy Phan, T.T.; Kim, H.; Lee, K.D.; et al. Multimodal tumor-homing chitosan oligosaccharide-coated biocompatible palladium nanoparticles for photo-based imaging and therapy. Sci. Rep. 2018, 8, 500. [CrossRef] [PubMed]

4. Zhou, G.; Jiang, H.; Zhou, Y.; Liu, P.; Jia, Y.; Ye, C. Peptide-coated palladium nanoparticle for highly sensitive bioanalysis of trypsin in human urine samples. Nanomater. Nanotechnol. 2018, 8, 1-8. [CrossRef]

5. Liu, Y.; Wang, D.-D.; Zhao, L.; Lin, M.; Sun, H.-Z.; Sun, H.-C.; Yang, B. Polypyrrole-coated flower-like Pd nanoparticles (Pd NPs@PPy) with enhanced stability and heat conversion efficiency for cancer photothermal therapy. RSC Adv. 2016, 6, 15854-15860. [CrossRef]

6. Azizi, S.; Mahdavi Shahri, M.; Rahman, H.S.; Rahim, R.A.; Rasedee, A.; Mohamad, R. Green synthesis palladium nanoparticles mediated by white tea (Camellia sinensis) extract with antioxidant, antibacterial, and antiproliferative activities toward the human leukemia (MOLT-4) cell line. Int. J. Nanomed. 2017, 12, 8841-8853. [CrossRef] [PubMed]

7. Gan, P.P. Potential of plant as a biological factory to synthesize gold and silver nanoparticles and their applications. Rev. Environ. Sci. Biotechnol. 2012, 11, 169-206. [CrossRef]

8. Iravani, S. Green synthesis of metal nanoparticles using plants. Green Chem. 2011, 13, 2638-2650. [CrossRef]

9. Puja, P.; Kumar, P. A perspective on biogenic synthesis of platinum nanoparticles and their biomedical applications. Spectrochim. Acta A 2019, 211, 94-99. [CrossRef]

10. Klaus, T.; Joerger, R.; Olsson, E.; Granqvist, C.G. Silver based crystalline nanoparticles, microbically fabricated. Proc. Natl. Acad. Sci. USA 1999, 96, 13611-13614. [CrossRef]

11. Roh, Y.; Lauf, R.J.; McMillan, A.D.; Zhang, C.; Rawn, C.J.; Bai, J.; Phelps, T.J. Microbial synthesis and the characterization of metal substituted magnetites. Solid State Commun. 2001, 118, 529-534. [CrossRef]

12. Nair, B.; Pradeep, T. Coalescence of nanoclusters and formation of submicron crystallites assisted by Lactobacillus strains. Cryst. Growth Des. 2002, 2, 293-298. [CrossRef]

13. Yong, P.; Rowson, N.A.; Farr, J.P.G.; Harris, I.R.; Macaskie, L.E. Bioreduction and biocrystallization of palladium by Desulfovibrio desulfuricans NCIMB 8307. Biotechnol. Bioeng. 2002, 80, 369-379. [CrossRef] [PubMed]

14. Husseiny, M.I.; El-Aziz, M.A.; Badr, Y.; Mahmoud, M.A. Biosynthesis of gold nanoparticles using Pseudomonas aeruginosa. Spectrochim. Acta A 2007, 67, 1003-1006. [CrossRef] [PubMed]

15. Mukherjee, P.; Ahmad, A.; Mandal, D.; Senapati, S.; Sainkar, S.R.; Khan, M.I.; Parishcha, R.; Ajaykumar, P.V.; Alam, M.; Kumar, R.; et al. Fungus-mediated synthesis of silver nanoparticles and their immobilization in the mycelia matrix: A novel biological approach to nanoparticles synthesis. Nano Lett 2001, 1, 515-519. [CrossRef]

16. Mukherjee, P.; Ahmad, A.; Mandal, D.; Senapati, S.; Sainkar, S.R.; Khan, M.I.; Ramani, R.; Parischa, R.; Ajaykumar, P.A.; Alam, M.; et al. Bioreduction of AuCl4- ions by the fungus, Verticillium sp. and surface trapping of the gold nanoparticles formed. Angew. Chem. Int. Ed. 2001, 40, 3585-3588. [CrossRef]

17. Ahmad, A.; Senapati, S.; Khan, M.I.; Kumar, R.; Sastry, M. Extra-/intracellular, biosynthesis of gold nanoparticles by an alkalotolerant fungus, Trichothecium sp. J. Biomed. Nanotechnol. 2005, 1, 47-53. [CrossRef]

18. Kowshik, M.; Arhtaputre, S.; Kharrazi, S.; Vogel, W.; Urban, J.; Kulkarni, S.K.; Paknikar, K.M. Extracellular synthesis of silver nanoparticles by a silver-tolerant yeast strain MKY3. Nanotechnology 2003, 14, 95-100. [CrossRef]

19. Shenton, W.; Douglas, T.; Young, M.; Stubbs, G.; Mann, S. Inorganic-organic nanotube composites from template mineralization of tobacco mosaic virus. Adv. Mater. 1999, 11, 253-256. [CrossRef]

20. Lee, S.W.; Mao, C.; Flynn, C.; Belcher, A.M. Ordering of quantum dots using genetically engineered viruses. Science 2002, 296, 892-895. [CrossRef]

21. Merzlyak, A.; Lee, S.W. Phage as template for hybrid materials and mediators for nanomaterials synthesis. Curr. Opin. Chem. Biol. 2006, 10, 246-252. [CrossRef] [PubMed] 
22. Mittal, A.K.; Chisti, Y.; Banerjee, U.C. Synthesis of metallic nanoparticles using plants. Biotechnol. Adv. 2013, 31, 346-356. [CrossRef] [PubMed]

23. Thakkar, K.N.; Mhatre, S.S.; Parikh, R.Y. Biological synthesis of metallic nanoparticles. Nanomedicine 2010, 6, 257-262. [CrossRef] [PubMed]

24. Fahmy, S.A.; Mamdouh, W. Garlic oil-loaded PLGA nanoparticles with controllable size and shape and enhanced antibacterial activities. J. Appl. Polym. Sci. 2018, 135, 46133. [CrossRef]

25. Vijilvani, C.; Bindhu, M.R.; Frincy, F.C.; AlSalhi, M.S.; Sabitha, S.; Saravanakumar, K.; Devanesan, S.; Umadevi, M.; Aljaafreh, M.J.; Atif, M. Antimicrobial and catalytic activities of biosynthesized gold, silver and palladium nanoparticles from Solanum nigurum leaves. J. Photochem. Photobiol. B Biol. 2020, 202, 111713. [CrossRef]

26. Isaac, R.; Gobalakrishnan, S.; Rajan, D.; Wu, R.-J.; Pamanji, S.R.; Khagga, M.; Baskaralingam, V.; Chavali, M. An Overview of Facile Green Biogenic Synthetic Routes and Applications of Platinum Nanoparticles. Adv. Sci. Eng. Med. 2013, 5, 763-770. [CrossRef]

27. Siddiqi, K.S.; Husen, A. Fabrication of metal and metal oxide nanoparticles by algae and their toxic effects. Nanoscale Res. Lett. 2016, 11, 363. [CrossRef]

28. Rao Yenumula, V.N.D.; Nagadesi, P.K. Biogenic Synthesis of Engineered Platinum Nanomaterial: A Review. Int. J. Sci. Eng. Dev. Res. 2018, 3, 216-220.

29. Phan, T.T.V.; Huynh, T.-C.; Manivasagan, P.; Mondal, S.; Oh, J. An Up-To-Date Review on Biomedical Applications of Palladium Nanoparticles. Nanomaterials 2020, 10, 66. [CrossRef]

30. Macaskie, L.E.; Mikheenko, I.P.; Omajai, J.B.; Stephen, A.J.; Wood, J. Metallic bionanocatalysts: Potential applications as green catalysts and energy materials. Microb. Biotechnol. 2017, 10, 1171-1180. [CrossRef]

31. Narayanan, K.B.; Sakthivel, N. Biological synthesis of metal nanoparticles by microbes. Adv. Colloid Interface Sci. 2010, 156, 1-13. [CrossRef] [PubMed]

32. Dreyfuss, M.S.; Chipley, J.R. Comparison of effects of sublethal microwave radiation and conventional heating on the metabolic activity of Staphylococcus aureus. Appl. Environ. Microbiol. 1980, 39, 13-16. [CrossRef] [PubMed]

33. Khanna, P.; Kaur, A.; Goyal, D. Algae-based metallic nanoparticles: Synthesis, characterization and applications. J. Microbiol. Methods 2019, 163, 105656. [CrossRef] [PubMed]

34. Venkatesan, J.; Lowe, B.; Anil, S.; Manivasagan, P.; Kheraif, A.A.A.; Kang, K.H.; Kim, S.K. Seaweed polysaccharides and their potential biomedical applications. Starch 2015, 67, 381-390. [CrossRef]

35. Mukunthan, K.; Balaji, S. Cashew apple juice (Anacardium occidentale L.) speeds up the synthesis of silver nanoparticles. Int. J. Green Nanotechnol. 2012, 4, 71-79. [CrossRef]

36. Kharissova, O.V.; Dias, H.V.R.; Kharisov, B.I.; Perez, B.O.; Victor, M.; Perez, J. The greener synthesis of nanoparticles. Trends Biotechnol. 2013, 31, 240. [CrossRef]

37. Bhattacharya, D.; Gupta, R.K. Nanotechnology and potential of microorganisms. Crit. Rev. Biotechnol. 2005, 25, 199-204. [CrossRef]

38. Mandal, D.; Bolander, M.E.; Mukhopadhyaya, D.; Sarkar, G.; Mukherjee, P. The use of microorganism for the formation of metal nanoparticles and their applications. Appl. Microbiol. Biotechnol. 2006, 69, 485-492. [CrossRef]

39. Shankar, S.S.; Rai, A.; Ankamwar, B.; Singh, A.; Ahmad, A.; Sastry, M. Biological synthesis of triangular gold nanoprisms. Nat. Mater 2004, 3, 482-488. [CrossRef]

40. Kasthuri, J.; Kathiravan, K.; Rajendiran, N. Phyllanthin-assisted biosynthesis of silver and gold nanoparticles: A noval biological approach. J. Nanopart. Res. 2009, 11, 1075-1085. [CrossRef]

41. Azzazy, H.M.E.; Mansour, M.M.H.; Samir, T.M.; Franco, R. Gold nanoparticles in the clinical laboratory: Principles of preparation and applications. Clin. Chem. Lab. Med. 2012, 50, 193-209. [CrossRef] [PubMed]

42. Li, X.; Xu, H.; Chen, Z.S.; Chen, G. Biosynthesis of nanoparticles by microorganisms and their applications. J. Nanomater 2011, 1-16, 270974. [CrossRef]

43. Sankar, R.; Manikandan, P.; Malarvizhi, V.; Fathima, T.; Shivashangari, K.S.; Ravikumar, V. Green synthesis of colloidal copper oxide nanoparticles using Carica papaya and its application in photocatalytic dye degradation. Spectrochim. Acta A 2014, 121, 746. [CrossRef]

44. Castro, L.; Blázquez, M.L.; Muñoz, J.A.; González, F.; García-Balboa, C.; Ballester, A. Biosynthesis of gold nanowires using sugar beet pulp. Process Biochem. 2011, 46, 1076. [CrossRef] 
45. Dubey, S.P.; Lahtinen, M.; Sillanpaa, M. Tansy fruit mediated greener synthesis of silver and gold nanoparticles. Process Biochem. 2010, 45, 1065-1071. [CrossRef]

46. Sathishkumar, M.; Krishnamurthy, S.; Yun, Y.S. Immobilization of silver nanoparticles synthesized using the Curcuma longa tuber powder extract on cotton cloth for bactericidal activity. Biores. Technol. 2010, 101, 7958-7965. [CrossRef] [PubMed]

47. Ghoreishi, S.M.; Behpour, M.; Khayatakashani, M. Green synthesis of silver and gold nanoparticles using Rosa damascena and its primary applications in electrochemistry. Physica E Low Dimens. Syst. Nanostruct. 2011, 44, 97-104. [CrossRef]

48. Duran, N.; Marcato, P.D.; Duran, M.; Yadav, A.; Gade, A.; Rai, M. Mechanistic aspects in the biogenic synthesis of extracellular metal nanoparticles by peptides, bacteria, fungi, and plants. Appl. Microbiol. Biotechnol. 2011, 90, 1609-1624. [CrossRef]

49. Punjabi, K.; Choudhary, P.; Samant, L.; Mukhejee, S.; Vaidya, S.; Chowdhary, A. Biosynthesis of Nanoparticles: A Review. Int. J. Pharm. Sci. Rev. Res. 2015, 30, 219.

50. Malik, P.; Shankar, R.; Malik, V.; Sharma, N.; Mukherjee, T.K. Green chemistry based benign routes for nanoparticle synthesis. J. Nanopart. 2014, 2014, 302429. [CrossRef]

51. Nasrollahzadeh, M.; Sajadi, S.M. Synthesis and characterization of titanium dioxide nanoparticles using Euphorbia heteradena Jaub root extract and evaluation of their stability. Ceram. Int. 2015, 41, 14435. [CrossRef]

52. Akhtar, M.S.; Panwar, J.; Yun, Y.S. Biogenic synthesis of metallic nanoparticles by plant extracts. ACS Sustain. Chem. Eng. 2013, 1, 591-602.

53. Panchal, M.; Kongor, A.; Mehta, V.; Vora, M.; Bhatt, K.; Jain, V. Heck-type olefination and Suzuki coupling reactions using highly efficient oxacalix [4] arene wrapped nanopalladium catalyst. J. Saudi Chem. Soc. 2018, 22, 558-568. [CrossRef]

54. Göde, C.; Yola, M.L.; Yılmaz, A.; Atar, N.; Wang, S. A novel electrochemical sensor based on calixarene functionalized reduced graphene oxide: Application to simultaneous determination of Fe (III), Cd (II) and $\mathrm{Pb}$ (II) ions. J. Colloid Interface Sci. 2017, 508, 525-531. [CrossRef]

55. Valkenier, H.; Malytskyi, V.; Blond, P.; Retout, M.; Mattiuzzi, A.; Goole, J.; Bruylants, G. Controlled functionalization of gold nanoparticles with mixtures of calix [4] arenes revealed by infrared spectroscopy. Langmuir 2017, 33, 8253-8259. [CrossRef]

56. Granata, G.; Paterniti, I.; Geraci, C.; Cunsolo, F.; Esposito, E.; Cordaro, M.; Consoli, G.M. Potential eye drop based on a calix [4] arene nanoassembly for curcumin delivery: Enhanced drug solubility, stability, and anti-inflammatory effect. Mol. Pharm. 2017, 14, 1610-1622. [CrossRef]

57. Fahmy, S.A.; Brüßler, J.; Alawak, M.; El-Sayed, M.M.H.; Bakowsky, U.; Shoeib, T. Chemotherapy Based on Supramolecular Chemistry: A Promising Strategy in Cancer Therapy. Pharmaceutics 2019, 11, 292. [CrossRef]

58. Nimse, S.B.; Kim, T. Biological applications of functionalized calixarenes. Chem. Soc. Rev. 2013, 42, 366-386. [CrossRef]

59. Guo, D.-S.; Liu, Y. Supramolecular chemistry of p-sulfonatocalix [n] arenes and its biological applications. Acc. Chem. Res. 2014, 47, 1925-1934. [CrossRef]

60. Fahmy, S.A.; Ponte, F.; Abd El-Rahman, M.K.; Russo, N.; Sicilia, E.; Shoeib, T. Investigation of the host-guest complexation between 4-sulfocalix [4] arene and nedaplatin for potential use in drug delivery. Spectrochim. Acta A Mol. Biomol. Spectrosc. 2018, 193, 528-536. [CrossRef]

61. Menon, S.; Rajeshkumar, S.; Kumar, V. A review on biogenic synthesis of gold nanoparticles, characterization, and its applications. Resour. Effic. Technol. 2017, 3, 516-527. [CrossRef]

62. Shahverdi, A.R.; Shakibaie, M.; Nazari, P. Basic and practical procedures for microbial synthesis of nanoparticles. In Metal Nanoparticles in Microbiology; Rai, M., Duran, N., Eds.; Springer: Berlin/Heidelberg, Germany, 2011; pp. 177-197.

63. Anjana, P.M.; Bindhu, M.R.; Umadevi, M.; Rakhi, R.B. Antibacterial and electrochemical activities of silver, gold, and palladium nanoparticles dispersed amorphous carbon composites. Appl. Surf. Sci. 2019, 479, 96-104. [CrossRef]

64. Ismail, E.; Khenfouch, M.; Dhlamini, M.; Dube, S.; Maaza, M. Green palladium and palladium oxide nanoparticles synthesized via Aspalathus linearis natural extract. J. Alloy. Compd. 2017, 695, 3632-3638. [CrossRef] 
65. Vaghela, H.; Shah, R.; Pathan, A. Palladium Nanoparticles Mediated Through Bauhinia variegata: Potent In vitro Anticancer Activity Against MCF-7 Cell Lines and Antimicrobial Assay. Curr. Nanomater. 2018, 3, 168-177. [CrossRef]

66. Lebaschi, S.; Hekmati, M.; Veisi, H. Green synthesis of palladium nanoparticles mediated by black tea leaves (Camellia sinensis) extract: Catalytic activity in the reduction of 4-nitrophenol and Suzuki-Miyaura coupling reaction under ligand-free conditions. J. Colloid Interface Sci. 2017, 485, 223-231. [CrossRef] [PubMed]

67. Sathishkumar, M.; Sneha, K.; Kwak, I.S.; Mao, J.; Tripathy, S.J.; Yun, Y.S. Phyto-crystallization of palladium through reduction process using Cinnamom zeylanicum bark extract. J. Hazard. Mater. 2009, 171, 400-404. [CrossRef]

68. Sathishkumar, M.; Sneha, K.; Yun, Y.S. Palladium nanocrystals synthesis using Curcuma longa tuber extract. Int. J. Mater. Sci. 2009, 4, 11-17.

69. Yang, X.; Li, Q.; Wang, H.; Huang, J.; Lin, L.; Wang, W.; Sun, D.; Su, Y.; Opiyo, J.B.; Hong, L.; et al. Green synthesis of palladium nanoparticles using broth of Cinnamomum camphora leaf. J. Nanopart. Res. 2010, 12, 1589-1598. [CrossRef]

70. Nadagouda, M.N.; Varma, R.S. Green synthesis of silver and palladium nanoparticles at room temperature using coffee and tea extract. Green Chem. 2008, 10, 859-862. [CrossRef]

71. Ghosh, S.; Nitnavare, R.; Dewle, A.; Tomar, G.B.; Chippalkatti, R.; More, P.; Chopade, B.A. Novel platinum-palladium bimetallic nanoparticles synthesized by Dioscorea bulbifera: Anticancer and antioxidant activities. Int. J. Nanomed. 2015, 10, 7477-7490.

72. Nasrollahzadeh, M.; Mohammad, S.S. Pd nanoparticles synthesized in situ with the use of Euphorbia granulate leaf extract: Catalytic properties of the resulting particles. J. Colloid Interface Sci. 2016, 462, $243-251$. [CrossRef] [PubMed]

73. Gurunathan, S.; Kim, E.; Han, J.W.; Park, J.H.; Kim, J.H. Green Chemistry Approach for Synthesis of Effective Anticancer Palladium Nanoparticles. Molecules 2015, 20, 22476-22498. [CrossRef] [PubMed]

74. Sharmila, G.; Fathima, M.F.; Haries, S.; Geetha, S.; Kumar, N.M.; Muthukumaran, C. Green synthesis, characterization and antibacterial efficacy of palladium nanoparticles synthesized using Filicium decipiens leaf extract. J. Mol. Struct. 2017, 1138, 35-40. [CrossRef]

75. Bhakyaraj, K.; Kumaraguru, S.; Gopinath, K.; Sabitha, V.; Kaleeswarran, P.R.; Karthika, V.; Sudha, A.; Muthukumaran, U.; Jayakumar, K.; Mohan, S.; et al. Eco-Friendly Synthesis of Palladium Nanoparticles Using Melia azedarach Leaf Extract and Their Evaluation for Antimicrobial and Larvicidal Activities. J Clust. Sci. 2017, 28, 463-476. [CrossRef]

76. Anand, K.; Tiloke, C.; Phulukdaree, A.; Ranjan, B.; Chuturgoon, A.; Singh, S.; Gengan, R.M. Biosynthesis of palladium nanoparticles by using Moringa oleifera flower extract and their catalytic and biological properties. J. Photochem. Photobiol. B Biol. 2016, 165, 87-95. [CrossRef] [PubMed]

77. Surendra, T.V.; Roopan, S.M.; Arasu, M.V.; Al-Dhabi, N.A.; Rayalu, G.M. RSM optimized Moringa oleifera peel extract for green synthesis of M. oleifera capped palladium nanoparticles with antibacterial and hemolytic property. J. Photochem. Photobiol. B Biol. 2016, 162, 550-557. [CrossRef]

78. Manikandan, V.; Velmurugan, P.; Park, J.H.; Lovanh, N.; Seo, S.K.; Jayanthi, P.; Park, Y.J.; Cho, M.; Oh, B.T. Synthesis and antimicrobial activity of palladium nanoparticles from Prunus x yedoensis leaf extract. Mater. Lett. 2016, 185, 335-338. [CrossRef]

79. Veisi, H.; Rashtiani, A.; Barjasteh, V. Biosynthesis of palladium nanoparticles using Rosa canina fruit extract and their use as a heterogeneous and recyclable catalyst for Suzuki-Miyaura coupling reactions in water. Appl. Organometal. Chem. 2016, 30, 231-235. [CrossRef]

80. Sharmila, G.; Haries, S.; Fathima, M.F.; Geetha, S.; Kumar, N.M.; Muthukumaran, C. Enhanced catalytic and antibacterial activities of phytosynthesized palladium nanoparticles using Santalum album leaf extract. Powder Technol. 2017, 320, 22-26. [CrossRef]

81. Tahir, K.; Nazir, S.; Li, B.; Ahmad, A.; Nasir, T.; Khan, A.U.; Shah, S.A.A.; Khan, Z.U.H.; Yasin, G.; Hameed, M.U. Sapium sebiferum leaf extract mediated synthesis of palladium nanoparticles and in vitro investigation of their bacterial and photocatalytic activities. J. Photochem. Photobiol. B Biol. 2016, 164, 164-173. [CrossRef]

82. Petla, R.K.; Vivekanandhan, S.; Misra, M.; Mohanty, A.K.; Satyanarayana, N. Soybean (Glycine max) leaf extract based green synthesis of palladium nanoparticles. J. Biomater. Nanobiotechnol. 2012, 3, 14-19. [CrossRef] 
83. Rabiee, N.; Bagherzadeh, M.; Kiani, M.; Ghadiri, A.M. Rosmarinus officinalis directed palladium nanoparticle synthesis: Investigation of potential antibacterial, antifungal and Mizoroki-Heck catalytic activities. Adv. Powder Technol. 2020, 15, 3983-3999. [CrossRef]

84. Ameri, A.; Shakibaie, M.; Rahimi, H.; Adeli-Sardou, M.; Raeisi, M.; Najafi, A.; Forootanfar, H. Rapid and Facile Microwave-Assisted Synthesis of Palladium Nanoparticles and Evaluation of Their Antioxidant Properties and Cytotoxic Effects Against Fibroblast-Like (HSkMC) and Human Lung Carcinoma (A549) Cell Lines. Biol. Trace Elem. Res. 2019, 197, 132-140. [CrossRef] [PubMed]

85. Mohana, S.; Sumathi, S. Multi-Functional Biological Effects of Palladium Nanoparticles Synthesized Using Agaricus bisporus. J. Clust Sci. 2020, 31, 391-400. [CrossRef]

86. Prasad, R.S.; Padvi, N.M.; Suryawanshi, S.S.; Shaikh, Y.I.; Chaudhary, L.S.; Samant, A.P.; Prasad, N.R. Bio-inspired synthesis of catalytically and biologically active palladium nanoparticles using Bos Taurus urine. SN Appl. Sci. 2020, 2, 754. [CrossRef]

87. Arsiya, F.; Sayadi, M.H.; Sobhani, S. Green synthesis of palladium nanoparticles using Chlorella vulgaris. Mater. Lett. 2017, 186, 113-115. [CrossRef]

88. Momeni, S.; Nabipour, I. A Simple Green Synthesis of Palladium Nanoparticles with Sargassum Alga and Their Electrocatalytic Activities Towards Hydrogen Peroxide. Appl. Biochem. Biotechnol. 2015, 176, 1937-1949. [CrossRef]

89. Zhan, G.; Huang, J.; Du, M.; Abdul-Rauf, I.; Ma, Y.; Li, Q. Green synthesis of Au-Pd bimetallic nanoparticles: Single-step bioreduction method with plant extract. Mater. Lett. 2011, 65, 2989-2991. [CrossRef]

90. Luo, F.; Yang, D.; Chen, Z.; Megharaj, M.; Naidu, R. One-step green synthesis of bimetallic Fe/Pd nanoparticles used todegrade Orange II. J. Hazard. Mater. 2016, 303, 145-153. [CrossRef]

91. Sivamaruthi, B.S.; Ramkumar, V.S.; Archunan, G.; Chaiyasut, C.; Suganthy, N. Biogenic synthesis of silver palladium bimetallic nanoparticles from fruit extract of Terminalia chebula-In vitro evaluation of anticancer and antimicrobial activity. J. Drug Deliv. Sci. Technol. 2019, 51, 139-151. [CrossRef]

(C) 2020 by the authors. Licensee MDPI, Basel, Switzerland. This article is an open access article distributed under the terms and conditions of the Creative Commons Attribution (CC BY) license (http://creativecommons.org/licenses/by/4.0/). 